\title{
Pertumbuhan dan Status Kesehatan Broiler yang Diberi Umbi Gembili sebagai Prebiotik Inulin
}

\section{Growth Performance and Health Status of Broiler that given Tuber of Gembili as Inulin Prebiotic}

\author{
N. Fajrih*, M. Khoirudin, dan A. F. Fanani \\ Fakultas Pertanian Perikanan dan Peternakan, Universitas Nahdlatul Ulama Lampung - Indonesia \\ *Corresponding E-mail: nunu.nuru191@gmail.com \\ (Diterima: 15 November 2019; Disetujui: 22 Februari 2020)
}

\begin{abstract}
ABSTRAK
Tujuan penelitian yaitu untuk mengkaji pengaruh prebiotik alami yang bersumber dari inulin umbi Gembili dalam upaya meningkatkan kesehatan dan performa pertumbuhan broiler. Rancangan penelitian menggunakan rancangan acak lengkap (RAL) dengan 4 perlakuan dan 5 kali ulangan yang diisi masingmasing 10 ekor ayam. Perlakuan meliputi: P0 = Ransum kontrol tanpa tepung umbi Gembili, P1 = Ransum $+0,5 \%$ tepung umbi Gembili, P2 $=$ Ransum $+1,0 \%$ tepung umbi Gembili, dan P3 $=$ Ransum $+1,5 \%$ tepung umbi Gembili. Variabel yang diamati yaitu performa broiler (konsumsi ransum, PBB, dan FCR) dan persentase bobot organ limfoid (bursa fabrisius, tymus, dan limpa). Data yang diperoleh kemudian dianalisis ragam ANOVA, jika berpengaruh nyata maka dilanjutkan uji Duncan. Hasil penelitian memperlihatkan bahwa penggunaan inulin umbi Gembili memberikan pengaruh yang nyata $(\mathrm{P}<0,05)$ terhadap $\mathrm{PBB}$ dan FCR tetapi tidak berpengaruh terhadap konsumsi pakan pada broiler. Status kesehatan broiler yang meliputi persentasi bobot relatif bursa fabrisius juga menunjukkan perbedaan nyata $(\mathrm{P}<0,05)$ namun tidak berpengaruh pada berat relatif tymus dan limpa. Kesimpulan penelitian bahwa level tertinggi pemberian tepung umbi Gembili yaitu sebesar 1,5\% memberikan pengaruh paling baik terhadap peningkatan performa pertumbuhan dan status kesehatan broiler.
\end{abstract}

Kata kunci: broiler, umbi Gembili, prebiotik, inulin, performa, organ limfoid

\section{ABSTRACT}

The purpose of this study was to examine the effect of natural prebiotics sourced from Gembili tuber inulin in an effort to improve the health and growth performance of Broiler. The study design used a completely randomized design (CRD) with 4 treatments and 5 replications with 10 chickens each. The treatment includes $P 0$ : ration without Gembili tuber powder, P1 : ration + 0,5\% Gembili tuber powder, $P 2$ : ration $+1,0 \%$ Gembili tuber powder , P3 : ration $+1,5 \%$ Gembili tuber powder. The parameters observed were broiler performance (ration consumption, body weight gain and feed conversion) and percentage of lymphoid organ (bursa fabrisius, tymus, and spleen). The data obtained were then analyzed by the ANOVA variance, if it had a significant effect then Duncan's test continued. The results showed that feeding inulin of Gembili tuber was significantly $(P<0.05)$ on feed conversion and body weight gain, but not to feed consumption. The health status of broiler, which includes the percentage bursa of Fabricius weight, also shows real influence $(P<0,05)$, however not to the weight of the thymus and spleen. In conclusion, the higher level of feeding inulin of Gembili tuber of 1.5\% gives the best effect on improving the growth performance and health status of broilers.

Keywords: broiler, the tuber of Gembili, prebiotic, inulin, performance, lymphoid 


\section{PENDAHULUAN}

Jumlah penduduk Indonesia yang semakinmeningkatseiringberjalannnyawaktu, membuat kebutuhan daging khususnya daging ayam broiler juga mengalami peningkatan setiap tahunnya. Konsumsi daging ayam ras per kapita/tahun pada tahun 2018 meningkat $11,2 \%$ (573 gram) yaitu sebanyak $5,68 \mathrm{~kg}$ perkapita/tahun dibandingkan konsumsi tahun sebelumnya yang hanya sebesar 5,11 kg per kapita/tahun (BPS, 2018). Peningkatan kebutuhan daging tersebut memicu para ahli bidang peternakan untuk berusaha meningkatkan produktivitas ternak, antara lain dengan meningkatkan produksi ayam broiler, yaitu dengan pemberian aditif pakan misalnya pemberian antibiotik, obat atau hormon yang dapat memacu pertumbuhan. Namun, seiring berjalannya waktu dan kemajuan ilmu pengetahuan teknologi, maka penggunaan antibiotik, obat maupun hormon, sudah tidak menjadi rekomendasi yang dapat dipertahankan karena dapat menimbulkan residu pada produk unggas dan berdampak negatif pada konsumen. Sehingga berbagai alternatif pengganti antibiotik terus dikembangkan hingga saat ini yaitu antara lain dengan penggunaan prebiotik.

Prebiotik merupakan serat pangan yang termasuk karbohidrat yang tidak dapat dicerna oleh enzim pencernaan inang namun memberikan pengaruh yang baik dengan cara menstimulir pertumbuhan non patogen dalam saluran pencernaan inang (Ringø et al., 2010) dengan memacu pertumbuhan melalui aktifitas bakteri yang bermanfaat dalam usus (Choudhari et al., 2008). Pemberian prebiotik dapat dihubungkan dengan meningkatnya aktifitas dan jumlah bakteri menguntungkan baik Bifidobacteria maupun Lactobacillus yang pengaruhnya dapat menguntungkan inang, khususnya dari aspek peningkatan status kesehatan tubuh yang bermuara pada perbaikan perforrma produksi.

Sumber prebiotik alami yang dapat dimanfaatkan adalah inulin yang berasal dari umbi Gembili. Menurut Prabowo et al. (2014), bahwa Gembili mengandung serat pangan dan senyawa bioaktif yaitu inulin, selanjutnya disebutkan bahwa sebesar 14,629\% kandungan inulin yang terdapat dalam umbi Gembili. Inulin merupakan nutrien termasuk karbohidrat yang tidak dapat dicerna namun mampu merangsang pertumbuhan dan aktifitas bakteri non patogen dalam saluran cerna secara selektif, sehingga demikian memiliki fungsi sebagai prebiotik (Marsono, 2004). Disamping itu, Azhar (2009) mengemukakan bahwa inulin dapat mencegah penyakit kanker kolon dan dapat menghambat resiko kanker pada usus serta mampu membuat kadar gula darah menjadi normal.

Inulin hampir seluruhnya di dalam usus dapat difermentasi oleh mikrobia penghasil asam laktat sehingga produk akhirnya menjadi SCFA (short chain fatty acid) atau asam lemak rantai pendek dimana pada keadaan tersebut mengakibatkan $\mathrm{pH}$ usus menjadi turun yang pada akhirnya pertumbuhan dan aktifitas patogen menjadi terhambat, sebaliknya bakteri non patogen, khususnya Lactobacillus, dapat berkembang baik. Mekanisme tersebut berimplikasi pada peningkatan status kesehatan. Penelitian sebelumnya oleh Fajrih et al. (2014) menemukan bahwa tepung umbi dahlia yang juga mengandung inilin pada level optimal yaitu sebesar $1,2 \%$ berpengaruh positif terhadap kesehatan hewan inang yang ditandai dengan bobot bursa yang lebih besar dibanding kontrol yang merupakan indikator peningkatan sistem imun ayam.

Adapun penelitian sebelumnya oleh Fajrih dan Qulubi (2017) (unpublish) menemukan bahwa pemberian inulin yang bersumber dari umbi Gembili pada level $0,9 \%$ nyata meningkatkan pertumbuhan ikan yang meliputi berat dan panjang relatif ikan Nila Gift. Selanjutnya didukung oleh hasil penelitian Praveen et al. (2017) bahwa penambahan inulin berpengaruh nyata terhadap bobot badan, konsumsi dan FCR ayam pedaging dibandingkan perlakuan kontrol tanpa pemberian inulin. Berdasarkan hasil penelitian tersebut, maka pemberian inulin yang bersumber dari umbi Gembili 
diharapkan juga mampu meningkatkan performa pertumbuhan dan status kesehatan ayam pedaging. Tujuan penelitian ini adalah untuk mengkaji pengaruh berbagai level prebiotik alami yaitu inulin yang berasal dari tanaman umbi Gembili terhadap status kesehatan (bursa fabrisius, limpa, kelenjar tymus) dan PBB pada broiler.

\section{METODE}

\section{Waktu dan Tempat Penelitian}

Penelitian dilakukan pada bulan Juni hingga Agustus tahun 2019 di kandang percobaan Fakultas Pertanian, Perikanan, dan Peternakan Universitas Nahdlatul Ulama Lampung.

\section{Materi Penelitian}

Penelitian menggunakan broiler unsex strain MB 202, DOC umur 1 hari sebanyak 200 ekor. Ransum terdiri dari jagung giling, bungkil kedelai, bekatul, minyak nabati, tepung ikan, dicalsium pospat, mineral dan vitamin mix non antibiotik. Tepung umbi Gembili yang digunakan adalah produk buatan sendiri yang merupakan modifikasi dari metode Azhar (2009). Ransum penelitian disusun berdasarkan kandungan energi yaitu $3000 \mathrm{kkal} / \mathrm{kg}$ dan protein sebesar $21 \%$. Ransum perlakuan diberikan pada umur 7 hari hingga 35 hari atau selama pemeliharaan 4 minggu.

Ayam dipelihara selama 5 minggu, selama 1 minggu pertama ayam dipelihara pada kandang litter. Umur 1 minggu, ayam ditimbang untuk memperoleh bobot badan seragam kemudian dipindahkan ke kandang koloni dengan ukuran 1,5 x 1 meter sesuai dengan perlakuan dan ulangan. Ransum dan air minum diberikan secara ad libitum. Pada pemeliharaan minggu pertama ayam diberi pakan komersil kemudian dilanjutkan menggunakan ransum basal yang formulasinya disajikan pada Tabel 1. Umur 4 hari, ayam diberi vaksin Newcastle Disease (ND) dan vaksin Gumboro pada umur 13 hari untuk mencegah terserang penyakit.

Tabel 1. Komposisi dan kandungan nutrien ransum penelitian

\begin{tabular}{lc}
\hline Bahan Pakan & Ransum $(\mathrm{Kg})$ \\
\hline Jagung Giling & 56,50 \\
Bekatul & 6,00 \\
Bungkil Kedelai & 18,00 \\
Tepung Ikan & 15,00 \\
Minyak Nabati & 3,00 \\
Dicalsium pospat & 0,50 \\
Vitamin dan mineral & 1,00 \\
\hline Jumlah & 100,00 \\
\hline Kandungan Nutrien: & \\
Energi Metabolis (Kkal/Kg)** & $3.092,90$ \\
Protein Kasar (\%)* & 21,17 \\
Lemak (\%)* & 7,82 \\
Serat Kasar (\%)* & 2,72 \\
Ca (\%)* & 1,21 \\
P (\%)* & 1,05 \\
\hline Sumber: * Berdasarkan analisis proksimat di Laboratorium Nutrisi dan Makanan Ternak Fakultas Pertanian, & \\
$\quad$ Universitas Lampung. &
\end{tabular}




\section{Rancangan percobaan.}

Penelitian menggunakan rancangan acak lengkap (RAL) dengan 4 perlakuan yang diulang sebanyak 5 kali dan masingmasing petak diisi 10 ekor ayam. Sehingga jumlah ayam keseluruhan sebanyak 200 ekor. Perlakuan penelitian terdiri dari:

$\mathrm{P} 0=$ Ransum tanpa tepung umbi Gembili

$\mathrm{P} 1=$ Ransum + 0,5\% tepung umbi Gembili

$\mathrm{P} 2=$ Ransum $+1,0 \%$ tepung umbi Gembili

P3 $=$ Ransum $+1,5 \%$ tepung umbi Gembili

\section{Prosedur Penelitian}

Pemberian pakan komersil dilakukan pada umur 1 sampai 7 hari dan pakan basal diberikan pada umur 7 sampai 35 hari. Inulin umbi Gembili ditambahkan kedalam pakan basal kemudian diberikan pada broiler setiap pagi dan sore hari disertai pemberian air minum secara adlibitum. Data PBB (pertambahan bobot badan) ditimbang setiap akhir minggu, sedangkan data berat bursa fabricius, berat tymus dan berat limpa, diukur dari 2 ekor ayam dari tiap ulangan masingmasing pada akhir penelitian.

\section{Parameter Penelitian}

Parameter yang diamati dalam penelitian ini adalah performa broiler (konsumsi ransum, pertambahan bobot badan, dan konversi ransum) dan bobot organ limfoid (bobot bursa fabrisius, tymus, dan limpa).

\section{Konsumsi Ransum (g)}

Konsumsi ransum diperoleh dari jumlah ransum yang diberikan (g) dikurangi sisa ransum yang tidak termakan $(\mathrm{g})$.

\section{Pertambahan Bobot Badan (g)}

Ayam ditimbang setiap minggu kemudian dihitung dengan mengurangi bobot badan akhir (g) dengan bobot badan awal (g) untuk mendapatkan pertambahan bobot badan (g).

\section{Konversi Ransum}

Konversi ransum diperoleh dari hasil pembagian antara rata-rata konsumsi pakan dalam satu periode dengan rata-rata pertambahan bobot badan dalam satu periode itu pula.

Konversi/FCR dapat dihitung dengan menggunakan rumus berikut:

Konversi ransum $=\frac{\text { konsumsi ransum }}{\text { Pertambahan bobot badan }}$

4. Organ Limfoid (Bursa Fabrisius, Tymus, dan Limpa)

Bobot organ limfoid yaitu bursa fabrisius, tymus, dan limpa diseksio ditimbang kemudian dihitung dengan rumus sebagai berikut:

Bobot organ limfoid $(\%)=\frac{\text { Bobot organ limfoid }(\mathrm{g})}{\text { Bobot hidup }(\mathrm{g})} \times 100 \%$

\section{Analisis Data}

Data dianalisis ragam (ANOVA) dengan uji $\mathrm{F}$ pada taraf 5\% dan yang terdapat pengaruh nyata, dilanjutkan dengan uji Duncan (Steel dan Torrie, 1991).

\section{HASIL DAN PEMBAHASAN}

\section{Pertumbuhan dan Performa Broiler}

Penggunaan tepung umbi Gembili dalam penelitian ini menunjukkan pengaruh yang nyata $(\mathrm{P}<0,05)$ terhadap PBB dan konversi ransum pada broiler, namun terhadap konsumsi ransum tidak menunjukkan pengaruh yang nyata $(\mathrm{P}>0,05)$ (Tabel 2). Keragaman performa ayam sangat dipengaruhi oleh konsumsi pakan sehingga aspek konsumsi tersebut menjadi penting diukur dalam penelitian dengan tujuan untuk melakukan evaluasi terhadap nutrien pakan yang diberikan. Berdasarkan hasil penelitian diperoleh rerata jumlah konsumsi ransum pada setiap perlakuan hampir sama yaitu berkisar antara 2.500-2.526 g/ekor. Namun jika dilihat secara numerik, perlakuan kontrol menunjukkan konsumsi ransum yang lebih banyak yaitu sebesar 2.526,8 g/ekor dibandingkan dengan tiga perlakuan lainnya yang diberi prebiotik umbi Gembili (Tabel 2). Jumlah konsumsi yang tinggi pada perlakuan kontrol mungkin disebabkan karena tidak terdapat kandungan prebiotik dalam pakan yang pengaruhnya mampu meningkatkan 
Tabel 2. Rataan konsumsi, konversi, dan pertambahan bobot badan broiler selama pemeliharaan

\begin{tabular}{lcccc}
\hline Perlakuan & P0 & P1 & P2 & P3 \\
\hline Konsumsi (g/ekor) & $2.526,8 \pm 55,35$ & $2.513,2 \pm 120,90$ & $2.503,0 \pm 78,11$ & $2.500,4 \pm 92,22$ \\
Konversi & $1,77 \pm 0,05^{\mathrm{b}}$ & $1,66 \pm 0,06^{\mathrm{a}}$ & $1,69 \pm 0,06^{\mathrm{a}}$ & $1,63 \pm 0,05^{\mathrm{a}}$ \\
PBB (g/ekor) & $1.421,8 \pm 48,6^{\mathrm{b}}$ & $1.513,7 \pm 114,30^{\mathrm{ab}}$ & $1.478,1 \pm 45,28^{\mathrm{ab}}$ & $1.527,5 \pm 33,95^{\mathrm{a}}$ \\
\hline
\end{tabular}

Keterangan: Superskrip berbeda pada kolom yang sama menunjukkan perbedaan nyata $\mathrm{P}<0,05$. $\mathrm{P} 0$ $=$ Ransum tanpa tepung umbi Gembili, P1 $=$ Ransum $+0,5 \%$ tepung umbi Gembili, P2 = Ransum $+1,0 \%$ tepung umbi Gembili, P3 $=$ Ransum $+1,5 \%$ tepung umbi Gembili.

populasi non patogen didalam saluran pencernaan ayam sehingga nutrient yang dapat dicerna dan diserap pun lebih sedikit dibandingkan ayam yang mendapat perlakuan prebiotik. Berdasarkan hal tersebut sehingga menyebabkan ayam akan meningkatkan jumlah konsumsi ransum untuk memenuhi kebutuhan nutrient dalam tubuhnya. Hal ini didukung oleh penelitian Haryati dan Supriyati (2010) bahwa penggunaan prebiotik oligosakarida dari ubi jalar sebesar $0,2 \%$ pada ternak broiler memberikan efesiensi ransum yang lebih baik hingga pemeliharaan minggu ke 3 . Sedangkan penelitian Chen et al. (2005) menemukan bahwa produksi telur dan efesiensi pakan menjadi meningkat akibat pemberian $1 \%$ prebiotik oligofruktosa dan inulin dari akar chicory ke dalam ransum ayam petelur.

Konversi ransum atau FCR merupakan tolak ukur yang perlu dilakukan untuk mengetahui seberapa efisien pakan yang yang dapat dimanfaatkan oleh ternak. Sementara keberhasilan pemeliharaan ayam khususnya broiler dapat diukur dari nilai konversi ransum yang jika semakin rendah nilainya maka semakin baik pula kualitas ransum yang diberikan. Begitu pula sebaliknya jika angka konversi tinggi maka semakin banyak pula pakan yang dibutuhkan ayam untuk menaikkan bobot badannya yang artinya kualitas ransum yang diberikan kurang bagus. Nilai konversi ransum yang diperoleh dalam penelitian ini signifikan $(\mathrm{P}<0,05)$ dipengaruhi oleh pemberian tepung umbi Gembili selama periode pemeliharaan.

Nilai konversi ransum pada perlakuan P3 nyata lebih rendah dibandingkan perlakuan lainnya tetapi jika dilihat secara numerik perlakuan yang ditambahkan tepung umbi Gembili (P1, P2, P3) konversi ransumnya lebih rendah dibandingkan perlakuan kontrol tanpa umbi Gembili yaitu pada P0. Rendahnya nilai konversi ransum pada perlakuan yang diberi tepung Gembili, diduga disebabkan oleh kandungan inulin yang terdapat dalam umbi Gembili yang dapat meningkatkan jumlah bakteri non patogen yang terdapat dalam saluran cerna sehingga ikut membantu dalam peningkatan penyerapan nutrien kedalam tubuh. Selanjutnya tubuh dapat memanfaatkannya untuk membentuk bahkan menambah sel yang baru sehingga berdampak pada perbaikan angka konversi ransum. Menurut Alifian et al. (2018) bahwa, perbandingan antara ransum yang dikonsumsi dengan pertambahan berat badan yang dihasilkan ternak merupakan definisi dari konversi ransum. Konversi ransum, PBB dan berat karkas ayam pedaging dapat diperbaiki dengan menambahkan prebiotik kedalam ransum (Daud et al., 2009).

Performa pertumbuhan ayam broiler dapat diketahui dengan menggunakan variabel pengukuran pertambahan berat badan. Berdasarkan hasil analisa secara statistik bahwa penambahan tepung umbi Gembili secara nyata $(\mathrm{P}<0,05)$ mempengaruhi PBB broiler selama periode pemeliharaan. Perlakuan P3 menunjukkan berbeda dengan pelakuan $\mathrm{P} 0$, namun terlihat tidak berbeda dengan perlakuan $\mathrm{P} 1$ dan $\mathrm{P} 2$ berdasarkan data yang ditampilkan pada Tabel 2. Peningkatan PBB pada perlakuan penambahan tepung umbi Gembili terjadi karena inulin diketahui dapat meningkatkan jumlah BAL sehingga tercipta 
Tabel 3. Persentase bobot organ limfoid (bursa fabrisius, tymus, dan limpa)

\begin{tabular}{lcccc}
\hline Perlakuan & P0 & P1 & P2 & P3 \\
\hline Bursa fabrisius (\%) & $0,13 \pm 0,21^{\mathrm{b}}$ & $0,14 \pm 0,33^{\mathrm{b}}$ & $0,24 \pm 0,10^{\mathrm{ab}}$ & $0,46 \pm 0,43^{\mathrm{a}}$ \\
Tymus (\%) & $0,27 \pm 0,10$ & $0,28 \pm 0,04$ & $0,22 \pm 0,12$ & $0,27 \pm 0,08$ \\
Limpa (\%) & $0,24 \pm 0,02$ & $0,23 \pm 0,04$ & $0,24 \pm 0,05$ & $0,23 \pm 0,04$ \\
\hline
\end{tabular}

Keterangan: Superskrip berbeda pada kolom yang sama menunjukkan perbedaan nyata $\mathrm{P}<0,05$. $\mathrm{P} 0$ $=$ Ransum tanpa tepung umbi Gembili, P1 $=$ Ransum $+0,5 \%$ tepung umbi Gembili, P2 = Ransum $+1,0 \%$ tepung umbi Gembili, P3 = Ransum $+1,5 \%$ tepung umbi Gembili.

kondisi saluran pencernaan yang lebih sehat. Penelitian sebelumnya oleh Krismiyanto et al. (2015) bahwa penggunaan inulin asal umbi bunga dahlia nyata mempengaruhi penurunan jumlah E. Coli pada perlakuan kontrol sebesar $12,50 \times 10^{3} \mathrm{cfu} / \mathrm{g}$ dan pada perlakuan dengan tepung umbi dahlia sebanyak $5,25 \mathrm{x}$ $10^{2} \mathrm{cfu} / \mathrm{g}$. Kondisi tersebut berdampak pada tingginya kecernaan nutrien terutama protein. Hal tersebut dibuktikan oleh hasil penelitian Fanani et al. (2014) bahwa pemberian sumber inulin asal umbi bunga dahlia memperoleh nilai kecernaan tertinggi pada perlakuan tepung sebesar $52,87 \%$ dan perlakuan ekstrak sebesar 55,35\%, dengan nilai kecernaan terendah pada perlakuan kontrol yaitu hanya 48,92 .

Peningkatan PBB disamping ditunjang oleh kecernaan protein, diperkuat dengan nilai retensi nitrogen. Semakin tinggi retensi nitrogen, semakin banyak pula berperan dalam mendeposisikan protein, sehingga massa protein daging yang diperoleh pun menjadi tinggi (Maharani et al., 2013), akhirnya berdampak pada peningkatan PBB. Peningkatan PBB sangat didukung oleh massa protein daging yang menunjukkan terjadi peningkatan akibat pemberian tepung umbi dahlia sebesar 51,64 g dan ekstrak umbi dahlia sebanyak 53,77 g dibandingkan kontrol tanpa umbi dahlia yaitu 48,85 g (Fanani et al., 2014). Fenomena tersebut memberikan asumsi bahwa pemanfaatan protein akibat pemberian sumber inulin lebih tinggi. Hasil penelitian ini juga didukung oleh Nabizadeh (2012) bahwa bobot badan meningkat secara signifikan ketika ransum ditambahkan 1\% inulin, demikian pula Rebole et al. (2010) melaporkan bahwa inulin yang ditambahkan $10 \mathrm{~g}(1 \%)$ dan $20 \mathrm{~g}(2 \%) / \mathrm{kg}$ dalam ransum berbasis gandum dan barley, meningkatkan bobot badan broiler.

\section{Status Kesehatan Broiler}

Persentase bobot bursa fabricius dan bobot tymus merupakan salah satu indikator kekebalan dalam tubuh ayam. Pemberian sumber inulin dari umbi Gembili kedalam ransum memperlihatkan pengaruh yang nyata $(\mathrm{P}<0,05)$ terhadap persentase berat bursa fabricius pada broiler, tetapi tidak terhadap berat relatif tymus dan limpa (Tabel 3). Bobot bursa fabrisius akibat pemberian tepung umbi Gembili nyata lebih tinggi dibandingkan perlakuan kontrol tetapi antar perlakuan kontrol, P1 dan P2 menunjukkan tidak berbeda. Pemberian tepung umbi Gembili dapat meningkatkan sistem imun, sebab kandungan inulin yang terdapat dalam umbi Gembili berfungsi sebagai prebiotik yang mampu memperbanyak jumlah populasi bakteri non patogen sehingga membuat keberadaan bakteri patogen menjadi terhambat bahkan tereliminasi didalam saluran pencernaan. Berdasakan mekanisme tersebut sehingga usus menjadi lebih sehat dan berimplikasi terhadap peningkatan status kesehatan inang. Hal tersebut didukung oleh Penelitian Fajrih et al. (2014) sebelumnya bahwa penggunaan inulin asal umbi dahlia mampu meningkatkan sistem imun ayam yang ditandai dengan meningkatnya bobot organ limfoid khususnya bursa fabricius pada perlakuan yang mendapatkan tepung maupun ekstrak umbi dahlia pada level tertinggi tepung T3 sebesar 0,33 dan level tertinggi ekstrak T6 sebesar 0,31 dibandingkan perlakuan kontrol 
T0 yaitu hanya sebesar 0,12 .

Hal tersebut terjadi karena penggunaan tepung inulin hingga level tertinggi dapat menyediakan serat pangan yang dapat difermentasi oleh mikrobia non patogen khususnya BAL sehingga populasinya meningkat dengan adanya mekanisme exclusive competitive yang berdampak pada terhambatnya pertumbuhan patogen khususnya E. Coli.Bursa Fabricius merupakan pusat kekebalan humoral yang menghasilkan sel B yang disebutkan mempunyai fungsi yaitu mampu berdiferensiasi menjadi sel plasma dan merupakan salah satu kelompok Antigen Precenting Cell (APC) (Liu et al., 2012). Bursa berperan sebagai organ limfoid sekunder yang bertugas menghasilkan serta mematangkan sel B yang jika ada infeksi maka akan masuk ke dalam aliran darah kemudian bereaksi untuk melawan benda asing yang masuk ke dalam tubuh tersebut. Ayam yang memiliki bobot bursa yang besar disebutkan lebih tahan terhadap berbagai infeksi penyakit (Tizard, 1988).

Perlakuan tepung umbi Gembili tidak berpengaruh terhadap bobot relatif tymus. Organ limfoid primer yang mempunyai fungsi mengatur dan memproduksi diferensiasi limfosit $\mathrm{T}$ adalah tymus. Ukuran tymus sangat beragam, pada ayam yang baru lahir memiliki ukuran tymus yang relatif besar dan saat mencapai pubertas ukuran absolutnya lebih besar lagi. Saat ayam mengalami stress maka tymus akan mengalami atrofi yang lebih cepat sehingga ternak yang mati akibat terinfeksi penyakit yang cukup lama seringkali mempunyai ukuran tymus yang sangat kecil (Tizzard, 1998) mungkin terjadi karena tymus telah bekerja keras melawan infeksi. Ukuran tymus dipengaruhi oleh aktifitas yang berlebih ketika menghasilkan antibodi yang dibutuhkan oleh tubuh pada saat itu. Meningkatnya berat tymus dapat disebabkan oleh meningkatnya produksi sel-T pada organ tymus, namun demikian hal ini belum terlihat pada penelitian ini.

Sama halnya dengan limpa, meski hasil analisis statistik menunjukkan tidak beda nyata, tetapi jika dilihat secara numerik menunjukkan nilai yang cenderung lebih rendah akibat pemberian tepung umbi Gembili dibandingkan perlakuan kontrol (Tabel 3). Kecenderungan tersebut dapat dinyatakan bahwa perlakuan inulin mampu meningkatkan kesehatan ayam dikarenakan makrofag dapat mematikan antigen sebelum masuk ke dalam peredaran darah. Akhirnya, berdampak pada berkurangnya antigen yang dapat meringankan kerja limpa. Fenomena tersebut didukung oleh Merryana et al. (2006) bahwa kerja limpa dipengaruhi secara langsung oleh infeksi bakteri terhadap broiler dimana limpa berperan dalam menghasilkan limfosit sehingga daya tahan tubuh lebih baik yang tentunya berdampak pada ukuran limpa. Kondisi ini didukung oleh data bobot bursa fabrisius yang diberi tepung Gembili lebih tinggi dibanding kontrol atau P0, artinya bobot limpa yang cenderung rendah tidak bekerja keras untuk menanggulangi antigen. Sebaliknya, bobot limpa yang cenderung tinggi diasumsikan karena jumlah antigen yang masuk kedalam limpa lebih banyak sehingga limpa bekerja lebih berat yang menyebabkan ukurannya bertambah.

\section{KESIMPULAN}

Level tertinggi penggunaan tepung umbi Gembili yaitu pada perlakuan P3 sebesar $1,5 \%$ memberikan pengaruh paling baik terhadap peningkatan performa pertumbuhan dan status kesehatan broiler.

\section{UCAPAN TERIMA KASIH}

Ucapan terima kasih disampaikan kepada DRPM (Direktorat Riset dan Pengabdian pada Masyarakat) Kementerian Riset Teknologi dan Pendidikan Tinggi yang telah mendanai kegiatan penelitian ini melalui Program Hibah Penelitian dengan Skema Penelitian Dosen Pemula (PDP) tahun anggaran 2019 dengan SK nomor 806/SP2H/ LT/MONO/L2/2019. 


\section{DAFTAR PUSTAKA}

Alifian, M. D., Nahrowi, dan D. Evvyernie. 2018. Pengaruh Pemberian Imbuhan Pakan Herbal terhadap Performa Ayam Broiler. Buletin Makanan ternak 16(1): 47-57.

Azhar, M. 2009. Inulin sebagai prebiotik. J. Sainstek. 12(1): $23-26$.

BPS. 2018. Statistik Peternakan dan Kesehatan Hewan. Direktorat Jenderal Peternakan dan Kesehatan Hewan Kementerian Pertanian RI. Jakarta.

Chen, Y. C., C. Nakhtong, and T. C. Chen. 2005. Effects of chicory fructans on egg cholesterol in commercial laying hen. Int. J. Poult. Sci. 4(2): 109 - 114.

Choudhari., A. S. Shinde, and B. N. Ramteke. 2008. Prebiotics and probiotics as health promoter. Vet. World. 1(2): 59-6.

Daud, M., Wiranda, G. P., Komang, G. W. dan Agus, S. 2009. Penggunaan Prebiotik Oligosakarida Ekstrak Tepung Buah Rumbia (Metroxylon sago Rottb.) dalam Ransum terhadap Performa Ayam Pedaging. Agripet Volume 9(2): 15-20.

Fajrih, N., N. Suthama, and V. D. Yunianto. 2014. Body resistance and productive performances of crossbred local chicken fed inulin of dahlia tubers. Media Peternakan. 37(2): 108-114.

Fanani, A. F., Suthama, N. dan Sukamto, B. 2014. Retensi Nitrogen dan Konversi Pakan Ayam Lokal Persilangan yang diberi Ekstrak Umbi Dahlia (Dahlia variabilis) sebagai sumber inulin. J. Sains Peternakan. 12(2): 69-75.

Hartadi, H. 2005. Tabel Komposisi Pakan Untuk Indonesia. Gajah Mada University Press. Yogyakarta.

Haryati, T. dan Supriyati. 2010. Pemanfaatan senyawa oligosakarida dari bungkil kedelai dan ubi jalar pada ransum ayam pedaging. JITV. 15(4): $252-260$.

Krismiyanto, L., Suthama, N. dan Hanny,
I. W. 2015. Keberadaan bakteri dan perkembangan caecum akibat penambahan inulin dari umbi Dahlia (Dahlia variabilis) pada ayam kampung persilangan periode starter. JurnalJurnal Ilmu Peternakan. 24(3): 54 -60.

Liu, X.D., Feng, X. L., Zhou, B., Cao, R. B., Li, X. F. and Chen, P. Y. 2012. Isolation, modulatory functions on murine $\mathrm{B}$ cell development and antigen-specific immune respones of BP11, a novel peptide from the chicken bursa of Fabricius. Epub. 35(1): 107-13.

Maharani, P., N. Suthama, dan H. I. Wahyuni. 2013. Massa kalsium dan protein daging pada ayam arab petelur yang diberi ransum menggunakan Azolla microphylla. J. Anim. Agric. 2(1): 1827.

Marsono, Y. 2004. Serat Pangan dalam Perspektif Ilmu Gizi. Fakultas Teknologi Pertanian, Universitas Gadjah Mada.

Merryana, F. O., Nahrowi., M. Ridla., A. Setiyono, dan R. Ridwan. 2006. Performan broiler yang diberi pakan silase dan ditantang Salmonella typhimurium Prosiding Seminar Nasional AINI VI. Yogyakarta, 26-27 Juli 2007. Hal. 186-194.

Nabizadeh, A., O. Gevorkyan, and A. Golian. 2012. Effect of inulin on some hematological, immunological parameters and broiler chickens performance. J. Anim. Vet. Adv. 11(18): 3304-3311.

Prabowo, A. Y., T. Estiasih, dan I. Purwatiningrum. 2014. Umbi Gembili (Dioscorea esculenta L.) Sebagai Bahan Pangan Mengandung Senyawa Bioaktif: Kajian Pustaka. Jurnal Pangan dan Agroindustri. 2(3): 129-135.

Praveen, T., Munegowda, T., Indresh, H. C. and Jayanaik. 2017. Effect of Supplementation of Various Levels of Inulin on Growth Performance, Carcass Characteristics and Survivability in 
Raja II Broilers. Int. J. Curr. Microbiol. App. Sci. 6(9): 1470-1475.

Ringø, E., Olsen, R. E., Gifstad, T. Ø., Dalmo, R. A., Amlund, H., Hemre, G. L. and Bakke, A. M. 2010. Prebiotics in aquaculture: a review. Aquaculture Nutrition 16.

Rebole, A., L. T. Ortiz., M. L. Rodriguez., C. Alzueta., J. Trevino, and S. Velasco. 2010. Effects of inulin and enzyme complex, individually or in combination, on growth performance, intestinal microflora, cecal fermentation characteristics, and jejunal histomorphology in broiler chickens fed a wheat and barley-based diet. Int. J. Poult. Sci. 89(2): 276-278 .

Steel, R. G. D. dan J. H. Torrie. 1991. Prinsip dan Prosedur Statistika. Diterjemahkan oleh Bambang Sumantri. PT. Gramedia Pustaka Utama. Jakarta.

Tizard, 1988. Pengantar Imunologi Veteriner. Terjemahan: M. Partodiredjo. Airlangga University Press, Surabaya. 